\title{
Characterizations of Class 1 Integrons in Proteus mirabilis Isolated from Chickens at Chungcheong Province
}

\author{
Ji Youn Sung and Yong Gwan Byeon \\ Department of Biomedical Laboratory Science, Far East University, Eumseong 369-700, Korea
}

\section{충청지역의 닭으로부터 분리된 Proteus mirabilis 균주에 존재하는 Class 1 Integron의 유전형 분석}

\author{
성지연, 변용관 \\ 극동대학교 임상병리학과
}

\begin{abstract}
Antimicrobial agents or additives have commonly been used in domestic animals for the prevention and treatment of bacterial diseases. Unfortunately, this has resulted in the overgrowth of bacteria that is resistant to antimicrobial agents used by humans, and these might get disseminated to humans via the food. In this study, we investigated the prevalence of integrons, and characterized gene cassette arrays in Proteus mirabilis isolates obtained from chickens in Chungcheong province of Korea. Additionally, the correlation between gene cassette arrays and antimicrobial resistance rate was studied. A total of 26 Proteus mirabilis isolates were recovered from chickens in Chungcheong province in Korea. Antimicrobial susceptibility was determined by disk diffusion method. PCR and DNA sequencing were performed to characterize the gene cassette arrays. In addition, we employed repetitive extragenic palindromic sequence-based PCR (REP-PCR) method for clonality analysis of $P$. mirabilis strains. Of the 26 P. mirabilis isolates tested, 14 (53.8\%) isolates carried class 1 integrons, while class 2 and class 3 integrons were not detected in our study. The class 1 integrons harbored genes encoding resistance to aminoglycosides (aacCA5, $\operatorname{aadA2}$, aadA5 and $\operatorname{aad} A \lambda$ ), trimethoprim (dfrA17, and $d f r A 32$ ), lincosamides (linf) and erythromycin (ereA). In particular, the presence of class 1 integron had a significant correlatation to a high resistance rate of aminoglycoside and trimethoprim. We confirmed that class 1 integrons are widely disseminated in $P$. mirabilis isolates from chickens, contributing to the resistance to diverse antimicrobial agents in Korea. To prevent further spreading of antimicrobial resistant genes among P. mirabilis isolates, constant monitoring and clinical policing will become necessary.
\end{abstract}

Keywords: Chicken, Class 1 integron, Gene cassette, Proteus mirabilis

This is an Open Access article distributed under the terms of the Creative Commons Attribution Non-Commercial License (http://creativecommons.org/licenses/by-nc/4.0) which permits unrestricted non-commercial use, distribution, and reproduction in any medium, provided the original work is properly cited

Copyright @ 2015 The Korean Society for Clinical Laboratory Science. All rights reserved.
Corresponding author: Ji Youn Sung Department of Biomedical Laboratory Science, Far East University, Wangjang-ri, Gamgok-myeon, Eumseong 369-700, Korea Tel: 82-43-879-3668

E-mail: azaza72@naver.com

Received: May 20, 2015 Revised: None

Accepted: June 6, 2015

\section{서 론}

항균제의 광범위한 사용으로 인해 항균제 내성세균이 증가하게 되었을 뿐 아니라 다제 내성세균의 출현이 빈번해지고 있다(이 등,
2002; 이 등, 2005). 이러한 다제 내성세균은 병원성 세균에만 국한 되어 나타나는 것이 아니고 사람과 동물의 정상균무리에서도 빈번 하게 나타나고 있다. 특히 가축의 성장촉진을 위해 사료에 첨가되 어 왔던 항균제는 가축에 존재하는 정상균무리가 항균제에 대한 내 
성을 획득할 수 있는 근원이 되었다. 이렇게 발생된 항균제 내성세 균은 여러 경로를 통해 사람에 존재하는 정상균무리에 내성유전자 를 전달할 수 있어 내성세균의 확산에 대한 우려를 낳고 있다. 때문 에 세계 여러 국가에서는 치료를 목적으로 하는 경우 외에는 항균 제를 가축에 사용하는 것을 금지하였으며 국내에서도 항균제의 사 용을 제한하고 있다(Bernard, 2000; 권 등, 2007).

그러나 최근까지도 다량의 항균제가 특별한 제약 없이 사용되었 기 때문에 항균제 내성 세균이 가축에 다수 존재할 것으로 추정된 다. 권 등(2007)은 국내 축산환경에서 분리된 세균들의 항균제 내 성율이 높은 편이며 많은 수의 다제 내성세균이 존재한다고 보고하 였다. 또한 가축에 정상적으로 존재하는 장내세균이 내성유전자를 획득 할 경우 분변을 통해 하천, 토양, 및 지하수 등으로 확산 되어 더 많은 내성세균의 출현을 유도 할 수 있어 큰 문제가 되고 있다.

세균이 획득한 항균제 내성유전자를 다른 세균에 수평적으로 전 달하는데 중요한 역할을 하는 것이 integron이다. Integron은 다 양한 항균제 내성유전자 카세트를 포함하고 있고 이러한 내성유전 자를 장소-특이적인 재조합 기전에 의해 다른 세균에 전달할 수 있 다. 게다가 많은 항균제 내성 유전자 카세트를 종합적으로 축적할 수 있고 쉽게 발현시킬 수 있어 다제 내성 세균의 출현 및 증가에 중 요한 역할을 한다. 현재까지 integron은 최소한 6종류가 알려져 있 는데 사람은 물론 가축에 정상적으로 존재하는 장내세균에 가장 빈 번하게 나타나는 것은 class 1 과 class 2이다(Ploy 등, 2000). 그중 에서도 가장 빈번하게 검출되는 class 1 integron은 광범위 $\beta$-lactamase (bla) 및 dihydroflavonol-4-reductase ( $d f$ fr)와 acetyltransferase (aac), adenylyltransferase (aad) 및 phosphotransferase ( $a p h)$ 등의 aminoglycoside 수식효소 등 다양한 항균제 내성유전자를 카세트로 가지고 있다(Mazel, 2006).

항균제 내성유전자의 수평적 확산에 중요한 역할을 하는 integron은 장내세균에서 흔하게 발견된다. 본 연구에서는 충청지 역에서 자란 닭으로부터 분리된 Proteus mirabilis를 대상으로 integron의 빈도를 조사하고 integron내에 포함되어 있는 내성유 전자의 종류를 확인하여 축산분야에서 다량으로 사용되었던 항균 제로 인한 내성세균의 증가 및 확산에 있어 integron의 역할을 규 명하고자 하였다. 아울러 항균제 내성 정도를 파악하고 균주간의 clonality를 분석하여 내성세균의 확산 방지책을 마련하는데 필요 한 기초자료를 제공하고자 하였다.

\section{재료 및 방법}

\section{1. 균주의 수집}

2013년 8월 12일부터 9월 30일까지 충청지역 양계장 2곳에서
수집된 닭의 맹장으로부터 분리된 P. mirabilis 26균주를 대상으로 하였다. 분리된 균주는 Vitek GNI card (bioMerieux Vitek Inc., Hazelwood, Mo., USA)를 이용하여 동정하였다.

\section{2. 항균제 감수성 시험}

미국의 Clinical and Laboratory Standards Institute (CLSI) 지 침에 따라 amikacin, cefotaxime, ciprofloxacin, erythromycin, gentamicin, levofloxacin spectinomycin, streptomycin, trimethoprim, 哭 tobramycin (Oxoid, Basingstoke, UnitedKingdom) 에 대한 감수성을 Mueller-Hinton 한천(Difco, Cockeysville, $\mathrm{MD}, \mathrm{USA}$ )을 사용하여 디스크 확산법으로 확인하였다(CLSI, 2010). 정도관리를 위해서 Escherichia coli ATCC 25922를 동시 에 시험하여 허용범위내에 있는지를 확인하였다.

\section{Repetitive extragenic palindromic sequence-based $\mathrm{PCR}$ (REP-PCR)을 이용한 clone 선택}

대상 균주를 brain heart infusion broth (Difco)에 접종하여 $37^{\circ} \mathrm{C}$ 에서 하릇밤 진탕배양 한 후 배양액으로부터 DNA extraction kit(SolGent, Daejeon, Korea)을 사용하여 대상 균주의 염색 체 $\mathrm{DNA}$ 를 추출하였다. 추출된 염색체 $\mathrm{DNA}$ 를 주형 $\mathrm{DNA}$ 로 사용하 였고 시발체로는 ERIC2 (5'-AAGTAAGTGACTGGGGTGAGCG3')와 REP2-Dt (5'-NCGNCTTATCNGGCCTAC-3')로 명명된 장 내세균의 반복 서열을 이용하였다(Shannon and French, 2004). 증폭반응은 DNA 추출액 $(5.0 \mu \mathrm{L}), 10 \times$ Taq buffer $(5.0 \mu \mathrm{L}), 10$ mM dNTP mix (1.0 $\mu \mathrm{L})$, primer 각 20 pmol, 1.4 U Taq DNA polymerase (SolGent) 및 증류수를 혼합하여 $50 \mu \mathrm{L}$ 의 혼합액으로 시행하였다. Gene Amp PCR System 9600 (Perkin-Elmer Centus Corp., Norwalk, CT., USA)으로 $95^{\circ} \mathrm{C}$ 에서 5 분간 반응시 킨 후, $90^{\circ} \mathrm{C}$ 에서 40 초, $42^{\circ} \mathrm{C}$ 에서 1 분, $68^{\circ} \mathrm{C}$ 에서 7 분씩 35 회 증폭 반응시키고, $68^{\circ} \mathrm{C}$ 에서 15 분간 연장 반응시켰다. 증폭산물 $(10 \mu \mathrm{L})$ 은 ethidium bromide가 포함된 2\% agarose gels에 전기영동 한 후 BioDoc-14 Imaging system (UVP, Cambridge, UK)을 이용하 여 분석하였다. Band의 강도와 상관없이 band의 분자량과 개수로 각 균주를 비교하며, 두 개 이상의 band 차이가 있으면 역학적 상관 관계가 없는 것으로 판단하였다(정 등, 2003).

\section{Integron의 유전자 카세트 분석}

1) Integron의 검출

Class 1, 2, 및 3에 속하는 integron을 검출하기 위해 기존의 시 발체(Table 1)를 사용하여 다중 중합효소연쇄반응을 수행하였다. 대상 균주를 brain heart infusion broth (Difco)에 접종하여 $37^{\circ} \mathrm{C}$ 
Table 1. Oligonucleotide primers for the detection of integrons

\begin{tabular}{|c|c|c|c|}
\hline Primer pairs & Target & Sequence $\left(5^{\prime}-3^{\prime}\right)$ & Reference \\
\hline \multicolumn{4}{|c|}{ For multiplex PCR } \\
\hline Int1 F & int/1 & CAGTGGACATAAGCCTGTTC & Dillon et al, 2005 \\
\hline Int1 R & & CCCGAGGCATAGACTGTA & \\
\hline Int2 F & int/2 & GTAGCAAACGAGTGACGAAATG & Dillon et al, 2005 \\
\hline Int2 R & & CACGGATATGCGACAAAAAGGT & \\
\hline Int3 F & int $B$ & GCCTCCGGCAGCGACTTTCAG & Dillon et al, 2005 \\
\hline Int3 R & & ACGGATCTGCCAAACCTGACT & \\
\hline \multicolumn{4}{|c|}{ For sequencing } \\
\hline Int1' F & int/1 & GGCATCCAAGCAGCAAG & Lévesque et al, 1995 \\
\hline Int1' R & & AAGCAGACTTGACCTGA & \\
\hline
\end{tabular}

Abbreviations: $F$, forward; $R$, reverse.

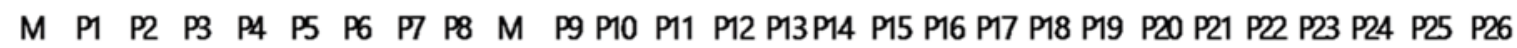

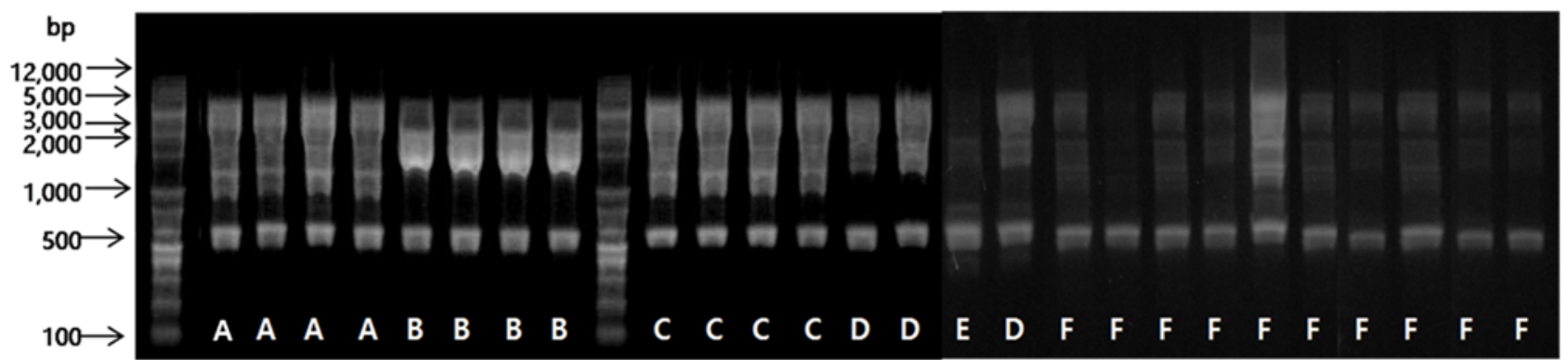

Fig. 1. Repetitive element sequence-based (REP)-PCR patterns of genomic DNA from twenty-six Proteus mirabilis. Lane M is $1 \mathrm{~kb}$ DNA size marker.

에서 하룻밤 진탕배양 한 후 배양액으로부터 DNA extraction kit (솔젠트)을 사용하여 염색체 DNA를 추출하였다. DNA 추출액(5 $\mu \mathrm{L}), 10 \times$ Taq buffer $(2.5 \mu \mathrm{L}), 10 \mathrm{mM}$ dNTP mix $(0.5 \mu \mathrm{L})$, primer 각 $10 \mathrm{pmol}, 0.7 \mathrm{U}$ Taq DNA polymerase (솔젠트) 및 증류 수를 혼합하여 총 부피 $25 \mu \mathrm{L}$ 의 반응용액을 만들었다. Gene Amp PCR System 9600 (Perkin-Elmer Centus Corp.)으로 $95^{\circ} \mathrm{C}$ 에서 5 분간 반응시킨 후, $94^{\circ} \mathrm{C}$ 에서 1 분, $59^{\circ} \mathrm{C}$ 에서 1 분, $72^{\circ} \mathrm{C}$ 에서 1 분씩 30 회 증폭 반응시키고, $72^{\circ} \mathrm{C}$ 에서 5 분간 연장 반응시켰다. 각각의 PCR 생산물을 ethidium bromide가 포함된 1.5\% agarose gel에 서 40 분간 전기영동하여 band를 확인하였다. PCR 생산물 band 의 위치가 약 $160 \mathrm{bp}, 788 \mathrm{bp}$, 및 $979 \mathrm{bp}$ 인 것을 각각 class 1, 2, 및 3 integron으로 간주하였다.

\section{2) Class 1 integron의 유전자 카세트 유전형 확인}

Class 1 integron내에 존재하는 유전자 카세트의 유전형을 확인 하기 위해 5' 보존영역(GGCATCCAAGCAGCAAG)과 3' 보존영역 의 분절(AAGCAGACTTGACCTGA)을 시발체로 하여 PCR을 수행 하였다(Lévesque 등, 1995). 다중 중합효소연쇄반응 때와 같은 조 성의 반응용액 $25 \mu \mathrm{L}$ 를 $95^{\circ} \mathrm{C}$ 에서 5 분간 반응시킨 후, $94^{\circ} \mathrm{C}$ 에서 1 분, $55^{\circ} \mathrm{C}$ 에서 1 분, $72^{\circ} \mathrm{C}$ 에서 4 분씩 30 회 증폭 반응시키고, $72^{\circ} \mathrm{C}$ 에
서 10 분간 연장 반응시켰다. 각각의 PCR 생산물을 ethidium bromide가 포함된 1\% agarose gel에서 40분간 전기영동하여 band를 확인한 후 염기서열 분석을 수행하였다. 5' 보존영역과 $3^{\prime}$ 보존영역의 분절을 시발체로 하여 얻어진 각각의 $\mathrm{PCR}$ 생산물을 염 기서열 분석한 뒤, 말단 부분에서 다시 새로운 시발체를 디자인하 여 PCR을 수행하고 염기서열 분석을 하는 일련의 과정을 되풀이 하는 primer walking 방법으로 전체 염기서열을 분석하였다.

\section{결 과}

\section{1. 항균제 감수성 양상}

총 26 균주의 P. mirabilis가 분리되었다. 이들이 같은 클론에서 유래되었는지를 확인하기 위하여 REP-PCR을 수행한 결과 총 6개 의(A, B, C, D, E, 및 F) 다른 band 패턴이 확인되었다(Fig. 1). 그 중 $\mathrm{F}$ 형을 나타낸 균주가 10 균주로 가장 많았으며 $\mathrm{A}$ 형, $\mathrm{B}$ 형, 및 $\mathrm{C}$ 형이 각각 4균주였다. 또한 $\mathrm{D}$ 형을 나타내는 균주는 3 균주였으며 한 균 주만이 E형을 나타냈다. 이들 26 균주를 대상으로 항균제 감수성 시험을 한 결과 cefotaxime에 대한 감수성이 $84.6 \%$ 로 가장 높았으 며 그 다음으로 amikacin (76.9\%)과 levofloxacin (76.9\%)에 대한 감수성이 높았다. 한편 erythromycin에 대해서는 검사한 균주 모 
Table 2. Characterizations of Proteus mirabilis strains isolated from chickens at Chungcheong province

\begin{tabular}{|c|c|c|c|c|c|c|c|c|c|c|c|c|}
\hline \multirow{2}{*}{ Isolates } & \multirow{2}{*}{ Gene cassettes } & \multirow{2}{*}{ REP PCR type } & \multicolumn{10}{|c|}{ Antimicrobial susceptibility } \\
\hline & & & AK & TOB & $\mathrm{CN}$ & $\mathrm{E}$ & $\mathrm{S}$ & $\mathrm{SH}$ & CTX & CIP & LEV & W \\
\hline P1 & $\operatorname{aac}(A 5-a a d A 7$ & A & $\mathrm{R}$ & R & $\mathrm{R}$ & $\mathrm{R}$ & $\mathrm{R}$ & $\mathrm{R}$ & S & 1 & S & $\mathrm{R}$ \\
\hline P2 & aacCA5-aadA7 & A & $\mathrm{S}$ & S & $\mathrm{R}$ & $\mathrm{R}$ & $\mathrm{R}$ & $\mathrm{R}$ & S & 1 & $\mathrm{~S}$ & $\mathrm{R}$ \\
\hline P3 & aac $C A 5-a a d A 7$ & A & $\mathrm{S}$ & $\mathrm{S}$ & $\mathrm{R}$ & $\mathrm{R}$ & $\mathrm{R}$ & $\mathrm{R}$ & S & | & $\mathrm{S}$ & $\mathrm{R}$ \\
\hline P4 & aacCA5-aadA7 & A & $\mathrm{S}$ & $\mathrm{S}$ & $\mathrm{R}$ & $\mathrm{R}$ & $\mathrm{R}$ & $\mathrm{R}$ & $\mathrm{R}$ & i & $\mathrm{S}$ & $\mathrm{R}$ \\
\hline P5 & - & B & $\mathrm{S}$ & I & $\mathrm{S}$ & $\mathrm{R}$ & $\mathrm{R}$ & $\mathrm{R}$ & S & $\mathrm{R}$ & S & $\mathrm{S}$ \\
\hline P6 & - & B & $\mathrm{S}$ & । & $\mathrm{S}$ & $\mathrm{R}$ & $\mathrm{R}$ & $\mathrm{R}$ & I & l & $\mathrm{S}$ & $\mathrm{S}$ \\
\hline P7 & - & B & $\mathrm{S}$ & S & $\mathrm{S}$ & $\mathrm{R}$ & $\mathrm{R}$ & $\mathrm{R}$ & S & 1 & $\mathrm{~S}$ & $\mathrm{~S}$ \\
\hline P8 & - & B & $\mathrm{S}$ & $\mathrm{S}$ & $\mathrm{S}$ & $\mathrm{R}$ & $\mathrm{R}$ & $\mathrm{R}$ & $\mathrm{S}$ & 1 & S & $\mathrm{S}$ \\
\hline P9 & aadA5-dfrA17 & C & $\mathrm{R}$ & $\mathrm{R}$ & $\mathrm{R}$ & $\mathrm{R}$ & $\mathrm{R}$ & $\mathrm{R}$ & $\mathrm{s}$ & $\mathrm{R}$ & $\mathrm{S}$ & $\mathrm{R}$ \\
\hline P10 & aadA5-dfrA17 & C & $\mathrm{R}$ & $R$ & $\mathrm{R}$ & $\mathrm{R}$ & $\mathrm{R}$ & $\mathrm{R}$ & $\mathrm{S}$ & $\mathrm{R}$ & $\mathrm{R}$ & $R$ \\
\hline P11 & aadA5-dfrA17 & C & $\mathrm{S}$ & $\mathrm{R}$ & $\mathrm{R}$ & $\mathrm{R}$ & $\mathrm{R}$ & $\mathrm{R}$ & S & $\mathrm{R}$ & $\mathrm{R}$ & $\mathrm{R}$ \\
\hline P12 & addA5-dfrA17 & c & $\mathrm{S}$ & $\mathrm{R}$ & $\mathrm{R}$ & $\mathrm{R}$ & $\mathrm{R}$ & $\mathrm{R}$ & $\mathrm{S}$ & $\mathrm{R}$ & R & $\mathrm{R}$ \\
\hline P13 & - & D & $\mathrm{S}$ & S & $\mathrm{S}$ & $\mathrm{R}$ & $\mathrm{R}$ & $\mathrm{R}$ & $\mathrm{S}$ & $\mathrm{R}$ & S & $\mathrm{R}$ \\
\hline P14 & - & D & $\mathrm{S}$ & $\mathrm{S}$ & $\mathrm{S}$ & $\mathrm{R}$ & $\mathrm{R}$ & $\mathrm{R}$ & $\mathrm{S}$ & l & S & $\mathrm{R}$ \\
\hline P15 & aadA5-dfrA17 & E & $\mathrm{S}$ & 1 & $\mathrm{~S}$ & $\mathrm{R}$ & $\mathrm{R}$ & $\mathrm{R}$ & $\mathrm{S}$ & $\mathrm{R}$ & $\mathrm{s}$ & $\mathrm{R}$ \\
\hline P16 & - & D & $\mathrm{S}$ & S & $\mathrm{S}$ & $\mathrm{R}$ & $\mathrm{R}$ & $\mathrm{R}$ & S & $\mathrm{R}$ & $\mathrm{S}$ & $\mathrm{R}$ \\
\hline P17 & $\operatorname{aadA2-linF}$ & $\mathrm{F}$ & $\mathrm{S}$ & $\mathrm{S}$ & $\mathrm{S}$ & $\mathrm{R}$ & $\mathrm{R}$ & $\mathrm{R}$ & S & $\mathrm{R}$ & $\mathrm{R}$ & $\mathrm{R}$ \\
\hline P18 & - & $\mathrm{F}$ & $\mathrm{S}$ & $\mathrm{S}$ & $\mathrm{S}$ & $\mathrm{R}$ & $\mathrm{S}$ & $\mathrm{S}$ & $\mathrm{S}$ & $\mathrm{s}$ & S & $\mathrm{S}$ \\
\hline P19 & dfrA32-ereA-aadA2 & $\mathrm{F}$ & $\mathrm{S}$ & $\mathrm{R}$ & $\mathrm{S}$ & $\mathrm{R}$ & $\mathrm{R}$ & $\mathrm{R}$ & I & $\mathrm{S}$ & S & $\mathrm{R}$ \\
\hline P20 & aadA2-linf & $\mathrm{F}$ & $\mathrm{R}$ & $\mathrm{S}$ & $\mathrm{S}$ & $\mathrm{R}$ & $\mathrm{R}$ & $\mathrm{R}$ & S & $\mathrm{R}$ & $\mathrm{R}$ & $\mathrm{R}$ \\
\hline $\mathrm{P} 21$ & - & $\mathrm{F}$ & $\mathrm{R}$ & $\mathrm{S}$ & $\mathrm{S}$ & $\mathrm{R}$ & $\mathrm{R}$ & $\mathrm{R}$ & $\mathrm{S}$ & $\mathrm{S}$ & S & $\mathrm{R}$ \\
\hline $\mathrm{P} 22$ & dfrA32-ereA-aadA2 & $\mathrm{F}$ & $\mathrm{R}$ & $\mathrm{R}$ & $\mathrm{S}$ & $\mathrm{R}$ & $\mathrm{R}$ & $\mathrm{R}$ & $\mathrm{S}$ & $\mathrm{S}$ & S & $\mathrm{R}$ \\
\hline P23 & - & $\mathrm{F}$ & $\mathrm{S}$ & $\mathrm{S}$ & $\mathrm{S}$ & $\mathrm{R}$ & $\mathrm{R}$ & $\mathrm{S}$ & $\mathrm{S}$ & $\mathrm{S}$ & $\mathrm{s}$ & $\mathrm{S}$ \\
\hline P24 & - & $\mathrm{F}$ & $\mathrm{S}$ & $\mathrm{S}$ & $\mathrm{S}$ & $\mathrm{R}$ & $\mathrm{R}$ & $\mathrm{S}$ & $\mathrm{S}$ & $\mathrm{S}$ & $\mathrm{S}$ & $\mathrm{S}$ \\
\hline P25 & - & $\mathrm{F}$ & $\mathrm{S}$ & $\mathrm{S}$ & $\mathrm{S}$ & $\mathrm{R}$ & $\mathrm{R}$ & $\mathrm{R}$ & S & $\mathrm{R}$ & R & $\mathrm{R}$ \\
\hline P26 & dfrA32-ereA-aadA2 & $\mathrm{F}$ & $S$ & $\mathrm{R}$ & $\mathrm{S}$ & $\mathrm{R}$ & $\mathrm{R}$ & $\mathrm{R}$ & I & I & S & $\mathrm{R}$ \\
\hline
\end{tabular}

Abbreviations: AK, amikacin; CIP, ciprofloxacin; CN, gentamicin; CTX, cefotaxime; E, erythromycin; LEV, levofloxacin; S, streptomycin; SH, spectinomycin; TOB, tobramycin; W, trimethoprim; S, susceptible; I, intermediate; R, resistant.

두가 내성을 보였으며, streptomycin에 대해서는 한 균주 그리고 spectinomycin에 대해서는 3균주를 제외한 모든 균주가 내성을 보였다.

\section{Class 1 integron 검출과 유전자 카세트의 유전형 확인}

Integron을 검출하기 위한 다중중합효소연쇄반응을 수행한 결 과 26 균주중 14 균주(53.8\%)에서 class 1 integron에 해당하는 약 $160 \mathrm{bp}$ 크기의 PCR 산물이 검출되었다. 반면 class 2 와 class 3 integron에 해당하는 약 $788 \mathrm{bp}$ 와 $979 \mathrm{bp}$ 크기의 PCR 산물은 검 출되지 않았다.

다중중합효소연쇄반응에서 $160 \mathrm{bp}$ 크기의 PCR 생산물이 검출 되었던 14 개의 균주를 대상으로 유전자 카세트 유전형을 확인하기 위한 PCR과 염기서열 분석을 수행 한 결과 4종류의 class 1 integron이 확인되었다(Table 2). 검출된 5종류의 class 1 integron은 모두 aminoglycoside 내성에 관련된 유전자 카세트를 포 함하고 있었다. aadA2, aadA5, 및 aadA7 유전자 카세트는 streptomycin 및 spectinomycin에 대한 내성을 나타내는데 관여 하며 $a a c C A 5$ 유전자 카세트는 gentamicin 내성에 관여한다. 그 외 에도 trimethoprim 내성에 관여하는 $d f r A 17$ 및 $d f r A 32$ 유전자 카 세트와 lincosamides 내성에 관여하는 linF 및 erythromycin 내성
에 관여하는 ereA 유전자 카세트가 class 1 integron 내에 존재하 고 있었다.

\section{고 찰}

항균제는 사람이나 동물을 치료하기 위한 목적으로 사용되는 것 외에도 가축의 성장촉진을 위해 사료에 첨가되거나, 세균의 증식을 억제 하기 위한 목적으로 각종 생활용품에 첨가되어 왔다. 이로 인 한 항균제 내성세균의 확산은 병원이라는 제한된 환경에 국한되지 않고 지역사회에 널리 퍼지게 되었으며 특히 축산환경에서의 내성 세균의 증가는 가축에서 사람으로 내성세균이 전파될 수 있어 심각 한 문제가 되고 있다(권 등, 2007).

본 연구에서는 국내에서 대표적으로 사육되고 있는 가축 중 하 나인 닭으로부터 장내세균인 P. mirabilis 총 26균주를 분리하여 integron의 존재여부에 따른 항균제 내성양상을 조사하였다. 본 연 구에서 검출된 모든 class 1 integron내에는 streptomycin 및 spectinomycin에 대한 내성을 나타내는 유전자 카세트가(aadA2, $a a d A 5$, 및 $a a d A$ ᄁ 포함되어 있었다. 국내에서도 유사한 보고가 있 었는데 강 등(2005)은 동물과 사람에서 분리된 대장균이 포함하고 있는 class 1 integron에 가장 많은 빈도로 존재하는 것이 $a a d A$ 유 
전자 카세트라고 했다. Wei 등(2013)도 사람에서 분리된 P. mirabilis를 대상으로 class 1 integron을 검출하여 유전자 카세트를 분 석하였는데 $a a d A$ 유전자 카세트가 가장 빈번하게 존재한다고 했 다. 한편, integron을 포함하고 있는 균주들은 모두 streptomycin 및 spectinomycin 항균제에 내성인 것으로 나타났다. 그러나 class 1 integron을 포함하고 있지 않은 균주들도 대부분 이 두 항 균제에 내성을 보여 P. mirabilis 균주가 이 항균제들에 높은 내성 을 나타내는 것은 class 1 integron의 유무보다는 다른 요인에 의한 것으로 추정된다. 따라서 이를 규명하기 위해서는 추가적인 연구가 필요할 것으로 사료된다.

Gentamicin 내성에 관여하는 $a a c C A 5$ 유전자 카세트를 포함하 는 균주는 모두 gentamicin에 내성을 나타냈으며 $a a d A 5$ 유전자 카세트를 갖는 4개의 균주도 gentamicin에 내성을 나타냈다. 또한 amikacin에 내성을 나타내는 3균주와 tobramycin에 내성을 나타 내는 8균주는 모두 $a a d A$ 유전자 카세트를 포함하는 integron을 가 지고 있었다. 즉 aminoglycoside 내성 유전자 카세트를 포함하는 integron을 가지는 균주는 integron을 갖고 있지 않은 균주보다 aminoglycoside 항균제에 대해 아주 높은 내성율을 보였다. 게다 가 dfrA17및 dfrA32유전자 카세트를 포함하는 integron을 가지 고 있는 균주는 모두 trimethoprim에 내성을 나타낸 반면 integron이 없는 균주는 12 균주 중 5 균주만 내성을 보였다. 이전 의 보고에서도 integron을 포함하는 균주는 integron을 가지고 있 지 않은 균주보다 여러 항균제들에 대해 고도의 내성율을 보인다고 하였다(Marchant 등, 2013).

한편 26균주 중 class 2 와 class 3 integron을 가지고 있는 균주 는 없었다. Class 1 과 class 2 integron은 사람은 물론 동물에서 분 리된 장내 정상균무리에서 가장 빈번하게 검출되는 integron으로 알려져 있다(Goldstein 등, 2001). 또한 장내세균과에 속하는 세균 의 경우 class 2 integron을 보유하는 경우가 빈번하며(White 등, 2001) class 3 integron 또한 덜 빈번하지만 보고가 되고 있다. 그러 나 본 연구에서는 class 1 integron 만이 검출되었는데 이는 class 1 integron이 닭에서 분리된 P. mirabilis에서도 내성확산에 주도 적인 역할을 하고 있음을 시사한다.

이상의 결과에서 충청지역의 닭에서 분리된 P. mirabilis 균주에 확산되어 있는 class 1 integron에는 aminoglycoside, erythromycin, lincosamides, 및 trimethoprim 내성에 관여하는 유전자 카세트가 포함되어 있는 것으로 나타났다. 또한 P. mirabilis 균주 가 다양한 항균제 내성유전자 카세트가 포함된 integron의 보유를 통해 많은 항균제에 대해 내성을 나타낼 수 있음이 확인되었다. 따 라서 가축에서 다제 내성세균의 출현 및 증가에 중요한 역할을 하 는 integron의 확산에 대한 지속적인감시가 필요할 것으로 사료된다.

\section{요 약}

최근까지도 세균 감염증 치료 또는 성장촉진을 목적으로 가축에 게 광범위하게 항균제를 사용해 왔으며, 이는 사람에게 보편적으로 사용되는 항균제들에 대한 내성세균의 출현 및 확산을 유도했다. 이렇게 출현한 다제 내성세균은 사람에게 음식을 통해 전달되고 내 성유전자를 확산시킬 수 있어 더 큰 문제가 되고 있다. 본 연구에서 는 충청지역에서 사육된 닭으로부터 분리된 Proteus mirabilis 균 주를 대상으로 integron의 빈도 및 integron의 존재에 따른 항균제 내성 비율의 변화를 조사하였다. 총 26 균주의 Proteus mirabilis 가 분리되었으며 이 균주를 대상으로 항균제 감수성 검사와 $\mathrm{PCR}$ 및 DNA 염기서열분석을 통한 integron의 유전자 카세트 분석이 이루 어졌다. 또한 extragenic palindromic sequence-based PCR (REP-PCR) 방법을 이용하여 P. mirabilis 균주들의 clonality를 확 인하였다. P. mirabilis 26균주 중 14 균주(53.8\%)가 class 1 integrons을 가지고 있음이 확인되었다. Class 1 integron 내에는 aminoglycoside (aacC, aadA), trimethoprim (dfrA), lincosamide (linF), 및 erythromycin (ereA) 등의 내성을 유도하는 유전 자 카세트가 위치해 있었다. 이들 class 1 integron을 포함하는 균 주는 integron을 포함하지 않는 균주보다 aminoglycoside 및 trimethoprim 계열 항균제에 대해 높은 내성율을 보였다. 본 연구 에서 class 1 integron은 P. mirabilis 균주들 사이에 광범위하게 확 산되어 있으며 다양한 항균제에 내성을 나타내는데 중요한 역할을 하고 있음이 확인되었다. 따라서 축사환경에 다제 내성세균의 출현 및 증가에 중요한 역할을 하는 integron의 확산에 대한 지속적인 감시가 필요할 것으로 사료된다.

\section{Acknowledgements: None}

Funding: None

Conflict of interest: None

\section{References}

1. Bernard Dixon. Antimicrobials as growth promoters: risks and alternatives. ASM News. 2000,66:264-265.

2. CLSI. Performance Standards for Antimicrobial Susceptibility Testing; Sixteenth Informational Supplement. CLSI document M100-S20. Wayne, 2010, p 52-53. Clinical and Laboratory Standards Institute, Wayne, Pennsylvania.

3. Dillon B, Thomas L, Mohmand G, Zelynski A, Iredell J. Multiplex PCR for screening of integrons in bacterial lysates. J Microbiol Methods. 2005,62:221-232.

4. Goldstein C, Lee MD, Sanchez S, Hudson C, Phillips B, Register $\mathrm{B}$, et al. Incidence of class 1 and 2 integrases in clinical and commensal bacteria from livestock, companion animals, and 
exotics. Antimicrob Agents Chemother. 2001,45:723-726.

5. Jeong SH, Lee K, Chong Y, Yum JH, Lee SH, Choi HJ, et al. Characterization of a new integron containing VIM-2, a metallo- $\beta$-lactamase gene cassette, in a clinical isolate of Enterobactercloacae. J Antimicrob Chemother. 2003,51:397-400.

6. Kang HY, Jeong YS, Oh JY, Tae SH, Choi CH, Moon DC, et al. Characterization of antimicrobial resistance and class 1 integrons found in Escherichia coli isolates from humans and animals in Korea. J Antimicrob Chemother. 2005,55:639-644.

7. Kwon YI, Kim TW, Kim HY, Chang YH, Kwak HS, Woo GJ, et al. Monitoring of antimicrobial resistant bacteria from animal farm environments in Korea. Kor J Microbiol Biotechnol. 2007,1:1725.

8. Lee K, Lim JB, Yum JH, Yong D, Chong Y, Kim JM, et al. blavin-2 cassette-containing novel integrons in metallo- $\beta$-lactamaseproducing Pseudomonas aeruginosa and Pseudomonas putida isolates disseminated in a Korean hospital. Antimicrob Agents Chemother. 2002,46:1053-1058.

9. Lee K, Yum JH, Yong D, Lee HM, Kim HD, Docquier JD, et al. Novel acquired metallo- $\beta$-lactamase gene, bla(SIM-1), in a class 1 integron from Acinetobacter baumannii clinical isolates from Korea. Antimicrob Agents Chemother. 2005,49:4485-4491.
10. Lévesque C, Piché L, Larose C, Roy PH. PCR mapping of integrons reveals several novel combinations of resistance genes. Antimicrob Agents Chemother. 1995,39:185-191.

11. Marchant M1, Vinué L, Torres C, Moreno MA. Change of integrons over time in Escherichia coli isolates recovered from healthy pigs and chickens. Vet Microbiol. 2013,163:124-132.

12. Mazel D. Integrons: agents of bacterial evolution. Nature Rev Microbiol. 2006,4: 608-620.

13. Ploy MC, Lambert T, Couty JP, Denis F. Integrons: an antibiotic resistance gene capture and expression system. Clin Chem Lab Med. 2000,38:483-487.

14. Shannon KP, French GL. Increasing resistance to antimicrobial agents of Gram-negative organisms isolated at a London teaching hospital, 1995-2000. J Antimicrob Chemother. 2004,53:818825.

15. Wei Q, Hu Q, Li S, Lu H, Chen G, Shen B, et al. A novel functional class 2 integron in clinical Proteus mirabilis isolates. $J$ Antimicrob Chemother. 2014,69:973-976.

16. White PA, McIver CJ, Rawlinson WD. Integrons and gene cassettes in the enterobacteriaceae. Antimicrob Agents Chemother. 2001,45:2658-2661. 